\title{
Kentsel Ekoturizm: Arka Plandaki Aktörler ve Başarı Örnekleri
}

Urban Ecotourism: Actors in the Background and Success Cases

\author{
Füsun BAYKAL *, Emre ATABERK**, Hayriye ALPARSLAN*** \\ * (Sorumlu Yazar) Prof. Dr., Ege Üniversitesi Edebiyat Fakültesi Coğrafya Bölümü, 35100, İzmir. \\ E-posta:fusun.soykan@ege.edu.tr \\ ORCID: 0000-0002-4599-4235 \\ ** Öğr. Gör. Dr., Ege Üniversitesi Bergama Meslek Yüksekokulu Turizm ve Otel İşletmeciliği Programı, 35700, İzmir. \\ E-posta:emre.ataberk@ege.edu.tr \\ ORCID: 0000-0002-3338-4798 \\ *** Tezli Yüksek Lisans Öğrencisi, Ege Üniversitesi Sosyal Bilimler Enstitüsü, 35100, İzmir. \\ E-posta: hayriye83@gmail.com \\ ORCID:0000-0001-9625-8150
}

MAKALE BILGILERI

Makale işlem bilgileri:

Gönderilme tarihi: 6 Haziran 2020

Düzeltme: 10 Ağustos 2020

Düzeltme: 1 Ekim 2020

Kabul: 2 Ekim 2020

Anahtar sözcükler: Ekokent, Ekoturizm, Kent turizmi, Kentsel ekoturizm

ARTICLE INFO

Article history:

Submitted: 6 June 2020

Resubmitted: 10 August2020

Resubmitted: 1 October 2020

Accepted: 2 October 2020

Key words: Ecocity, Ecotourism,

Urban tourism, Urban ecotourism.

\section{ÖZ}

Bu makalenin konusu, kentsel ekoturizm ve onun arka planında etkili olan aktörler ile dünyadaki bașarı örneklerinden oluşmaktadır. Konunun ana problemi, ekoturizmin kentte nasıl uygulandığı sorusuna dayanmaktadır. Çalışmanın amacı da bu sorudan yola çıkarak kentsel ekoturizmi derinlemesine araştırmak, üstünlük ve yararlarına değinmek, ayrıca bazı uygulama örneklerini vermektir. Nitel araştırma yöntemiyle hazırlanan bu calıșmanın yaklasımı; bir mevcut durum saptaması, bir eylem araștırması, aynı zamanda turizm coğrafyası kapsamında gerçekleştirilen bir tematik derleme özelliği taşıdığı için çok yönlüdür. Derleme tekniği olarak kaynak taramasına gidilmiş, Türkçe, İngilizce ve Fransızca dillerindeki basılı ve web tabanlı alanyazından yararlanılmıștır. Kuramsala ait bașlıklar altında kentsel ekoturizme atıflar yapılarak ilișki kurulmuștur. Sonuc olarak kentsel ekoturizm, uygulanmasında birtakım zorluklara sahip olsa da kente korumacı yeni çekicilikler katması, kent turizmine yeni açılımlar getirmesi, kentin ekolojik değerlerine sahip çıkılması, kent halkının yaşam kalitesine olumlu etkilerinin olması ve ekoturistlerin de beklentilerini karşılaması açısından dünyada kabul görmeye devam edecektir.

\section{GiRiş}

Günümüzde çevresel ve kentsel sorunlar giderek büyüdüğü için kentsel sürdürülebilirlik son yirmi yılda ekonomik sürdürülebilirlikle giderek daha fazla yakınlaşmıştır (Chang ve Sheppard 2013). Sürdürülebilir ve yeşil kent hedefleri, bugün ekokent örnekleriyle hayata geçmektedir. Diğer taraftan kentlere katkı sağlayacak yeni kay- nak arayışlarında kent turizmi gündeme gelmektedir. Kent turizminde, turistlerin başlica motivasyonu kültür olmasına rağmen, günümüzde bambaşka amaçlarla kentlerin ziyaret edilmeye başlandığına tanık olunmaktadır. Bu yeni tip kent turizmine ve aynı zamanda ekoturizmin kentlerde uygulanmış biçimine "kentsel ekoturizm" denilmektedir. Kentin atıl durumdaki kısımlarının 
eko yaklaşımlarla yenilenerek dinlenme, eğlenme, öğrenme, spor ve macera amaçlı park-bahçe, su eğlence park1, botanik parkı, doğal yaşam parkı, açık hava müzesi gibi dönüşümlere uğraması, kentte kilometrelerce uzanan yeşil kuşakların oluşturulması, kent turizmini kültür odaklı olmaktan öteye taşımıştır. Artık kentler, kültür turistleri kadar ekoturistleri de kentlere çekmeye başlamıştır. Yaklaşık yirmi yıldan bu yana kentsel ekoturizm adının geçmesine ve bazı kentlerin sıkı biçimde hazırlanmasına rağmen alanyazında sınırlı sayıda çalışmaya rastlanmaktadır. Bunun nedenlerinden biri, adına kentsel ekoturizm ya da kentsel yeşil turizm denilmeden, kentlerdeki rekreasyonel alanlarla ilgili araştırmaların olmasıdır. Ancak buradaki en önemli fark; sürdürülebilirlik ilkelerini ve ekoturizm felsefesini kente yerleştirmek, bunu yaparken de yerel halkı ve turisti birlikte eylemlere dâhil etmektir. Kaldı ki kentsel ekoturizm düzenlemeleri çok işlevli, eğitici ve deneyim yaşatan eko tasarımlar olarak diğerlerinden oldukça farklıdır. İşte aradaki bu farklar görülmeye başladıkça ve kentsel ekoturizmin başarılı örnekleri çoğaldıkça akademik araştırmalar da artacaktır.

Bu çalışmanın tasarımında ana temaya uygun üç başlık açılmıştır: Kentsel ekoturizmin arka planındaki aktörler; ekoturizmin kentlere taşınması ve kentsel ekoturizm-yeşil turizmin oluşmas1; başarı örnekleridir. Bu konu akışında kuramdan uygulamaya doğru bir sıra takip edilmiştir. Böylece birinci başlık altında, sürdürülebilirlik ve yavaş kavramları, ekokent modeli, ekoturizm, yeşil turizm ve kent turizmi türleri, kentsel ekoturizmle ilişkilendirilmektedir. İkinci bölümde kentlerde uygulanan ekoturizm ve yeşil turizmin amaçları, yürütülen çalışmalar, fırsatlar ve yararlar, geleneksel ekoturizme göre avantajlar konu edilmektedir. Üçüncü bölümdeki başarı örnekleri, Fransa, Kanada ve Yeni Zelanda'dan bazı kentlere aittir. Hepsinin tarihleri, kültürleri, iklimleri ve doğal kaynak değerleri birbirinden çok farklı olduğu için kentsel ekoturizm uygulamaları farklıdır. Ama hepsinde sürdürülebilirlik, korumacılık, sorumluluk ve sahiplenme etrafında birleşilmektedir. Çalışmanın sonuç ve değerlendirme kısmında bu tematik derlemeden elde edi- len sonuçlar yer almakta ve kentsel ekoturizmde araştırılabilecek konulara değinilmektedir.

\section{ILGILI ÇALIŞMALAR}

Kentsel ekoturizmle ilgili çalışmalar yaklaşık son yirmi yılın ürünüdür. İlk öncü çalışmada (Joppe ve Dodds 1998) ekoturizm ilkelerinin kentte yeşil turizm adiyla uygulanması ele alınmakta ve o güne kadar (1998) kentsel çevrelerde bu turizm türünün görülmediği belirtilmektedir. Yazarlar buna karşılık, Toronto'da 1996 yılında Yeşil Turizm Derneği'nin kurulması ve bir yeşil turizm haritasını hazırlamasından sonra; Toronto'nun yükselen yeşil ya da çevre dostu kurumsal imajı yeşil ortaklıkların başladığını belirtmektedirler. Daha sonra 2002 yılındaki bir çalışmada (Higham ve Lück 2002) kentsel ekoturizm olgusunun ekoturizm tanımlarılya çelişkiler içinde olduğu analiz edilmiş, Yeni Zelanda'dan üç örnek verilmiş ve son olarak kentlerde ekoturizm girişimlerinin yararları tartışılmıştır.

Kentsel ekoturizmin boyutları üzerine odaklanan bir çalışmada (Wu vd. 2009) gelişimin göstergelerini saptamak üzere "bulanık sayı yaklaşı$m \imath$ " ile üç boyutlu hedefleme modeli kullanılmıştır. Sonuçta çevresel boyutun ekonomik boyuttan daha önemli olduğu ortaya çıkmıştır. Weaver (2015) kentsel ekoturizmin beş bileşenden meydana geldiğini ileri sürmekte, "kitle ekoturizmi" kavramına açıklık getirmektedir. Ayrıca, kitle ekoturizminin sürdürülemez kitle turizmine dönüşme olasılığının yüksek olması nedeniyle "kapsamlı kitle ekoturizmi" modelini önermektedir. Bu modele göre; bütünsel bir ekosistem yaklaşımı söz konusudur ve dönüştürücü eğitim çıktıları elde edilerek "derin" öğrenme deneyimleri kazanılmakta ve küresel ölçekte çevrenin güçlenmesi desteklenmektedir. Türkiye'den Isparta örneğiyle kentsel ekoturizmi ele alan tek çalışma İşçi ve arkadaşlarına (2018) aittir. Makalede; Isparta kent içi ve yakın çevresinin doğal ve kültürel değerleri kullanılarak rotalar belirlenmiştir. Bu doğrultuda yerel yönetimlerin ve ilgili paydaşların sinerji ve iş birliği oluşturmaları istenmiştir. Kentsel ekoturizmin rota belirleme ve doğaya dayalı etkinlikler kapsamında ele alınması, Türkiye'de bu turizm türünün birçok kentte (İs- 
tanbul, Eskişehir, Antalya vb.) kendine özgü formunun doğabileceğini göstermiştir.

Kentsel ekoturizmin kentler için yeni bir yaklaşım olması nedeniyle kuramsal eserler arasında çelişkili görüşler yer almakta, geliştirmek için yenilikler önerilmektedir. Alanyazında kuramsal eserlerin bir bölümünde örnekler yer almaktadır. Türkçe alanyazında ise kentsel ekoturizmi kuramsal boyutta derinlemesine irdeleyen, turizmdeki güncel gelişmelerle ilgisini kuran, dünyadan örneklerin tanıtıldığı bir çalışma olmadığ için bu makalede bu boşluğun doldurulması amaçlanmıştır. Ayrıca değerlendirme bölümünde bazı araştırma konuları önerilerek, yeni çalışmaların yapılmasına aracılık edilmiştir.

\section{YÖNTEM}

Nitel araştırma yöntemiyle hazırlanan bu çalışmada; alanyazında yeni bir konu olan kentsel ekoturizme ilişkin derinlemesine bilgilere ulaşılmak istenmiştir. Çalışmadaki yaklaşım üç şekilde tanımlanabilir: Kentsel ekoturizmin mevcut durumunu saptamak, onu yeni bir olgu kabul ederek eylem araştırması yapmak ya da bir tematik derleme hazırlamaktır. Sonuçta hepsinin bu makaledeki araştırma tekniği alanyazın taramasıdır. Derleme çalışmaları yalnızca alanyazından tek tek alıntı yapıp onları özetlemek değil, araştırmacının fikirlerini de yazarak bir senteze gitmesidir (Herdman 2006). Bu doğrultuda ana temayı çevreleyen konular kentsel ekoturizmle bütünleştirilmiştir. Son olarak kentsel ekoturizm, kentsel coğrafi mekânlarda gerçekleşen bir turizm türü olduğu için, turizm coğrafyasının hatta kentsel yerleşim coğrafyasının ilgi alanında kalmakta ve konu coğrafyanın neden-sonuç, karşılıklı ilgi ve dağılış ilkelerine bağlı kalınarak ele alınmaktadır.

\section{KENTSEL EKOTURIZMIN ARKA PLANINDAKI AKTÖRLER}

Bu çalışmada öncelikle; kentsel ekoturizmi besleyen ve tamamlayan, onunla yan yana giden, k1sacası bu turizm türünün gelişmesinde rol oynayan arka plandaki önemli aktörler olarak ekokent, yavaş şehir, ekoturizm, yeşil turizm ve kent turizmi kavramlarına açıklık getirilmekte, hepsinin kentsel ekoturizmle bağlantısı kurulmaktadır.

\section{Sürdürülebilirlik, Kent ve Turizm}

Sürdürülebilir kentler, toplum taşıma ve yenilenebilir enerji kullanan araçların öne çıtığı, üretim-tüketim-atık dengesinin kurulduğu, ekolojik ayak izini en aza indirme çabalarının olduğu, doğal yaşamın saygı gördüğü, tüm altyapı hizmetlerinden kent halkının eşit düzeyde yararlandığ 1 yerleşmelerdir. Kentlerde 1990'larda akillı kent kavramı doğmuştur. Akıllı kent girişimi, bir rekabet üstünlüğü olarak kabul edilmektedir (Meydan Yıldız 2016). En başarılı sürdürülebilir kent örneklerden biri olan İsviçre'nin Lozan kentinde belediye, sürdürülebilir gelişme, yaşam kalitesini iyileştirme, çevreyi koruma ve dinamik bir ekonomi yaratmayı hedef olarak belirlemiştir. Doğal mekânların korunmasında kentsel tüketicilerin yeşil mirasa sadık kalmalarına ve sürdürülebilir gelişime gönüllü katılımına çok önem verilmektedir (Ville de Lausanne 2006). Sürdürülebilir turizm, turistik talebin artmasıyla oluşan karmaşık sorunlara çözüm üretebilmek için politikaların geliştirilmesi ve tüm paydaşlarla birlikte bir turizm vizyonunun oluşturulması sırasında devreye girmekte (Urban Strategy Partners 2017), kentsel ekoturizmin de en temel yapı taşı olmaktadır.

\section{Şehir, Seyahat ve Turizm İçin Yeni Bir Kavram: "Yavaş"}

Yavaş şehir (Sakin kent/Cittaslow) hareke$t i$, küreselleşmenin yarattığı popüler kültür mekânlarından biri olmak istemeyen, yerel kimliği koruma anlayışında olanların oluşturduğu bir birlik girişimidir. Yavaş şehir yaklaşımının en önemli ve öncelikli ilkesi, yerel halkın tüm süreçlere (eğitim, dayanışma, rehberlik, üretim, satış vd.) katılmasıdır. Yavaş şehir unvanı almak, bir marka kazanmak demektir. Bu da ekoturizm, kültür turizmi ve kırsal turizmin gelişmesini kolaylaştırmaktadır. Seferihisar, Türkiye'deki ilk Cittaslow olarak turizmde önemli gelişmeler kat etmiştir. Yavaş seyahat, çevre ve sağlık açısından sorunlar yaratmayan, doğa dostu ve düşük karbonlu bir seyahattir. Yavaş turizm, sosyo-ekonomik faydaların yerel halka adil şekilde dağıtıldığı, çevreye olan baskıların engellendiği, doğa dostu kişilerin bir araya geldiği bir sorumlu turizm hareketidir (Tekin 2017). Yavaş şehirler, bi- 
rer kentsel ekoturizm örneği sayılabilir. Çünkü her ikisinde de doğaya, insana, kültürel mirasa sahip çıkılmakta, kentsel yaşam kalitesi merkeze alınmaktadır. Yavaş seyahat ve yavaş turizm de kentsel ekoturizmin ayrılmaz birer parçasıdır.

\section{Yeni Bir Yaklaşım, Farklı Bir Kent Modeli: Ekokent}

Bir şemsiye kavram olarak ekokent, sürdürülebilirliği amaçlayan, yenilenebilir enerji, yeşil yapı, ekolojik ve kültürel çeşitlilik, çevresel politikaları olan bir yaklaşımdır (Bibri ve Krogstie 2020). Ekokent, kendi kendine yetebilen bir kent idealinin yanı sıra, çağın yeniliklerine ve gelişmelerine yön veren teknolojik bir kent modelidir (Chang ve Sheppard 2013). Dünyada ilk örnek Dongtan Projesi'dir (2005). Birkaç örnek daha verilebilir: Avustralya City of Moreland ve Melbourne, Çin-Singapur-Tianjin Ecocity, Almanya Hamburg Eco-City, Birleşik Arap Emirlikleri Masdar Ekokenti vd. (Çetinkaya 2013). Türkiye'de bazı ekokent projeleri üniversiteler, belediyeler ve STK'lar tarafından oluşturulmaya çalışılmaktadır: Kocakır Eko-Kent Projesi (Eskişehir) ve Nilüfer Eko-Kent Projesi (Bursa) gibi (Kavcar 2017). Ekokentlerin birçoğu yeni inşa edilen kentlerdir ve onlar, sürdürülebilir, akıllı ve yeşil kent yaklaşımlarıyla şekillenmektedir (Meydan Yıldiz 2016). Yenileme ve sağlıklaştırma çalışmalarıyla ekokente dönüştürülen kentlerde, kentsel ekoturizmin gelişmesi çok daha kolaydır. Çünkü planlama çalışmalarında kent halkı ve turist, birlikte düşünülmektedir.

\section{Ekoturizm ve Yeşil Turizm}

Ekoturizm, doğal çevreye en az etkide bulunan ve yerel topluluklara ekonomik yararı amaçlayan bir alternatif bir turizm türüdür. Ekoturizmin dört ilkesi onun daha iyi tanınmasına firsat vermektedir (Zorzi 2015):

1. Çevre korunmalı ve doğru değerlendirilmelidir.

2. Kazançlar yerel aktörlere eşit olarak dağılmalıdır.

3. Ev sahibi toplumun ihtiyaçları göz önünde bulundurulmalıdır.

4. Özgün ama aynı zamanda sorumlu bir deneyim sunulmalıdır.
Ekoturizm turları genellikle 25 kişiyi aşmayan küçük gruplardan oluşmakta, konaklama tesisleri de 100 yatağı aşmamaktadır. Ekoturizmde iki konu öne çıkmaktadır: doğal çevrenin korunarak sürdürülebilirliğinin sağlanması; yerel kültürlere sayg1 gösterilmesi ve yerel halkın ekoturizmden fayda görmesidir (Ataberk vd. 2012). Ekoturizm birçok egzotik ülkede önemli bir endüstri haline gelmiştir: Nepal, Kenya, Meksika, Kosta Rika, Belize, Yeni Zelanda, Avusturalya, Ekvator, Brezilya, Şili, Hindistan vd. Türkiye'de ekoturizme yönelik kaynakların çoğunu milli parklar, tabiat koruma alanları, sulak alanlar gibi korunan bölgeler oluşturmaktadır. Türkiye Turizm Stratejisi 2023 'te ekoturizm bölgeleri ve koridorları belirlenmiştir. Yeşil turizmin ekoturizmin gelişmiş bir şekli olduğu ve sürdürülebilir kentsel turizmi yaratmada önemli rol oynadığı görüşü yanında, ekoturizm ve yeşil turizmin aynı olduğunu ileri sürenler de vardır. Kentli turistlerin giderek artan derecede doğaya ve doğala dönme istekleri, ekoturizm ya da yeşil turizmi canlı tutmaktadır (Andari 2016).

\section{Kent Turizmi}

Kent turizmi, turistlerin diğer toplumların tarihi ve kültürel mirası, yaşam tarzlarını, düşünce biçimlerini öğrenmek için gerçekleştirdikleri tüm ziyaretleri içine almaktadır. Kent turizmi üç kategoriye ayrılmaktadır: Tatil kentleri, tarih kentleri ve post-endüstriyel dönüşmüş-yeniden markalaşmış kentler (Spirou 2011). Turizm kentleri, genellikle çok nüfuslu olsa da Fransa'da yapılan bir araştırmaya göre; orta ölçekli kentlerin de bazı avantajları vardır: Turistlerin kısa mesafedeki köyleri, çiftlikleri, açık hava müzelerini, ilginç doğal oluşumları, eşsiz kültürel mirasları ziyaret edebilmesi, alışveriş, yüzme, yürüyüş gibi aktiviteleri aynı gün yapabilmesi gibi (Deschamps 2010). Kent turizminin günümüzde popüler hale gelmesinde; turist hareketliliğinin artması, kentlerin tatil geçirme yeri olarak kabul görmesi, turistik hizmetlerde yeniliklerin ve kalitenin artması en önemli etkenlerdir (Şarkaya İçellioğlu 2014). Kent turizminin geleceği için şunlara önem verilmelidir: kent mekânları çekici hale getirilmeli, turizmin altyapısı yenilenmeli, enformasyon 
kanalları belirlenmeli, kent kimliğini yansıtan sembollerle tanitım yapılmalı ve olumsuz imajlar ortadan kaldırılmalıdır (Emekli 2013). Kent turizmine önemli bir destek, doğal ortamlardaki ekoturizme herkesin erişememesinden dolayı "kentte herkes için ekoturizm" yaklaşımının gündeme gelmesidir. Böylece ekoturizm, kent turizmini yenileyici bir argüman olmaktadır.

\section{KENTSEL EKOTURIZM-YEŞIL TURIZM}

\section{Kentsel Ekoturizm}

Kanada'da 2004 yılında ilk kez düzenlenen I. Kentsel Ekoturizm Konferansi'nda kentsel ekoturizm hakkında şu ifadeler kullanılmıştır: "Kentlere yapılan doğa içerikli bir seyahat olup, kentlerin biyolojik ve sosyal çeşitliliğinin korunması, yaşam kalitesinin ve yeni is olanaklarının yaratılmasıdır" (İşçi vd. 2018). Konferansın bildirgesinde (Planeta.com 2006) kentsel ekoturizmin amaçları dört maddede toplanmıştır:

1. Doğal ve kültürel mirası korumak ve iyileştirmek,

2. Turizmin yararlarını en üst düzeye çıkarmak, kent halkının yatırımcı, ev sahibi ve rehber olarak turizme katılımını sağlamak,

3. Ziyaretçileri ve kent sakinlerini miras, koruma vd. konularda eğitmek,

4. Ekolojik ayak izini azaltmak.

Bu amaçlar, aynı zamanda kentsel ekoturizm neden ortaya çıtı? Neden gereksinim duyuldu? sorularına da büyük oranda yanıt vermektedir. Diğer ifadeyle bu dört madde, kentsel ekoturizme başvurulma nedenini ortaya koymaktadır. Ayrıca üç gereksinim daha eklenebilir: Birincisi; kent turizminde yeni açılımlara ihtiyaç duyulması, ikincisi; doğal mekânlarda ekoturizme katılma fırsatı olmayanların kente rahatça ulaşabilmesi, üçüncüsü; kentlerin turizmde rekabet şansının artırılması. Böylece kentlerde ekoturizmin arkasında birçok neden olduğu görülmektedir. Uzmanlara göre kentsel ekoturizm, geleneksel ekoturizme kıyasla şu avantajlara sahiptir (Fresison 2010; Tourisme Montréal Tolkit 2012; İşçi vd. 2018):
1. Ekoturistler kentlerde mevcut altyapıyı kullandıkları için çevreyi bozan yeni düzenlemelere gerek kalmamaktadır.

2. Kentteki doğal kaynakların ve biyoçeşitliliğin korunmasıyla sürdürülebilirlik sağlanmakta ve kentin yaşam kalitesine katkı verilmektedir.

3. Doğadaki ekoturizme oranla, kentte sürdürülebilirliği ve korumacilığg daha büyük ölçekte uygulama fırsatı bulunmaktadır. Çevre dostu sorumlu ve yaratıcı projeler, cesaretle, büyük bir katılımcılıkla ve hızlı biçimde kentlerde ekoturizme destek vermektedir.

4. Kentsel ekoturizm, mevsimselliğe daha az bağıml, istihdam yaratma ve gelir sağlama potansiyeli doğadaki ekoturizme göre daha yüksektir.

5. Kentsel ekoturizm, kent planlamasının en büyük destekçisi ve en uygun aracıdır.

6. Kentsel ekoturizmde mevcut yeşil alanlar iyileştirilmekte, eski sanayi bölgeleri, boş alanlar ve binalar rekreasyona yönelik yeni işlevler kazanmaktadır.

Wu ve arkadaşları (2009), sürdürülebilir kentsel ekoturizmin hedeflerini üç boyut üzerinde ikiye ayırarak şematize etmişlerdir (Şekil 1). Bunlar aynı zamanda kentsel ekoturizmin yararlarına da işaret etmektedir. Ancak üç boyutun birbiriyle ilişkili olduğu, birbirlerini tamamladıklarını gösteren çevrim hareketi şemada belli olmamaktadir.

Nüfusu artan ve mekânsal olarak genişleyen kentler, doğal alanları içine alarak adeta doğayı dışlamışlar, kırsal yerleşmeleri de kentsele dönüştürmüşlerdir. Şimdi ise kentlerin eskimiş bölgelerini yeşile döndürmenin yolları aranmaktadır (Jamaa 2010). Kentlilerin bu doğa talanına karşılık Osaka Turizm Derneği kentsel ekoturizmi; "turizmin bir kentin doğal ekosistemine saygı duyması" olarak öz biçimde tanımlamaktadır (Wu vd. 2009). Bu tanımı daha açacak olursak kentsel ekoturizm; sürdürülebilirlik hedefleri ve eko yaklaşımlardan hareketle çevresel, ekonomik ve sosyo-kültürel boyutlardaki ekoturizmin sorumluluk ve koruma kavramlarıla iç içe olarak kentlerde uygulanmasıdır. Kentsel ekoturizm kapsamında, sürdürülebilir enerji kullanımı teşvik edilmekte, ev- 


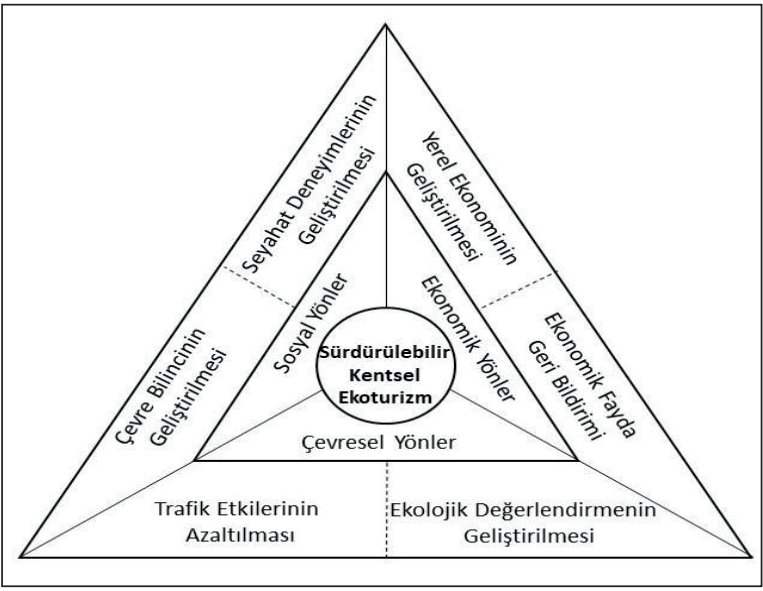

Şekil 1. Sürdürülebilir Kentsel Ekoturizmin Üç Boyutlu Hedefleme Modeli

Kaynak: Wu vd. 2009.

rensel ve yerel kültüre sayg1 gösterilmekte, toplu taşıma, bisiklet yolları, atık ve geri dönüşümle ilgili çalışmalar yürütülmekte, çevrenin (bölgenin) biyolojik çeşitliliği korunmakta, kamusal alanlar yaratılmakta, sivil toplum kuruluşları önemli faaliyetlerde bulunmaktadir.

Kentsel ekoturizmin başlıca mekânlarından biri olan parklar, kent halkı ve turistler için bir sosyal buluşma, eğlence, spor, farkındalık ve bilinç kazanma, hatta doğrudan fırsat eğitiminin verildiği yerlere dönüştürülmektedir. Çünkü bu parklarda bir müze, botanik bahçesi, lunapark, spor alanları ve çeşitli gösteriler için anfitiyatrolar yer almaktadır. Sonuç olarak, bu turizm türünün tek hedefi kentin korunmuş çevrelerinde turizm yapmak değil, ayrıca turistler ve sakinler arasında etkileşim yaratmak, turistlerin popüler alanları ve gerçek kent kültürünü keşfetmelerini sağlamak ve şüphesiz kentsel ekonomiye de değer kazandırmaktır. Böylece ekoturizm ilkelerinin kentte uygulanması, çevreci davranışı teşvik etmekte, ziyaretçilerin tutum ve değer yargıları olumlu yönde değişmektedir (Butty vd. 2014).

\section{Kentsel Yeşil Turizm}

Bazı araştırmacılar ve kurumlar, kentlerin doğal çevre olmadığını ileri sürerek, kentlerde ekoturizm yerine yeşil turizm ifadesini kullanmaktadırlar. Toronto Yeşil Turizm Derneği' ne göre yeşil turizm, ekoturizmin kentteki halidir ve şu yakıştırmalar yapılmaktadır: Operaya bisikletle gitmek, Toronto'nun büyüleyici semtlerinde dolaşmak, yürüyüş turlarına katılmak ve rehberden bilgi almak, çevreye karşı sorumlu olmak ve Toronto'nun doğal hazinelerini keşfetmektir (Green Tourism Association 2019). Dodds ve Joppe'a (2001) göre kentsel yeşil turizm; çevresel sorumluluk, yerel ekonomide canlılık, kültürel duyarlılık ve deneyimsel zenginliktir. Bir diğer bakış açısı; turistlerin yeşil turizm deneyimlerini çevrelerinde paylaştığ 1 için kent tanıtımında rol oynadığı ve kentle ilgili çeşitli sorunların çözülmesine katkı verdiği yönündedir (Tourisme Montréal Tolkit 2012). Kentsel dokuda park, bahçe ve korulukların önemli bir yer işgal ettiği, hobi ya da kentsel tarım bahçelerinin olduğu, otellerin kentsel peyzajda yeşilin çoğalmasını desteklediği kentlerde yeşil turizmden bahsedilmektedir. Sözgelimi Paris'teki bir otel, kentin en büyük sebze bahçesine (meyve ve sebze, çiçekler, aromatik bitkiler), kümeslere ve arı kovanlarına ev sahipliği yapmaktadır (Accor 2015).

Andari'nin Dunlop'tan aktardığına göre (2016) kentsel yeşil turizmin avantajları ya da faydaları sosyal, ekonomik ve çevresel olmak üzere üç boyutludur (Şekil 2):

Sosyal boyut: Yerel toplumların ortaklaşa öğrenmelerini teşvik etmekte, kentleri hakkında gurur ve aidiyet duymalarını sağlamaktadır. Ziyaretçiler için de etkileyici bir atmosfer olmaktadır.

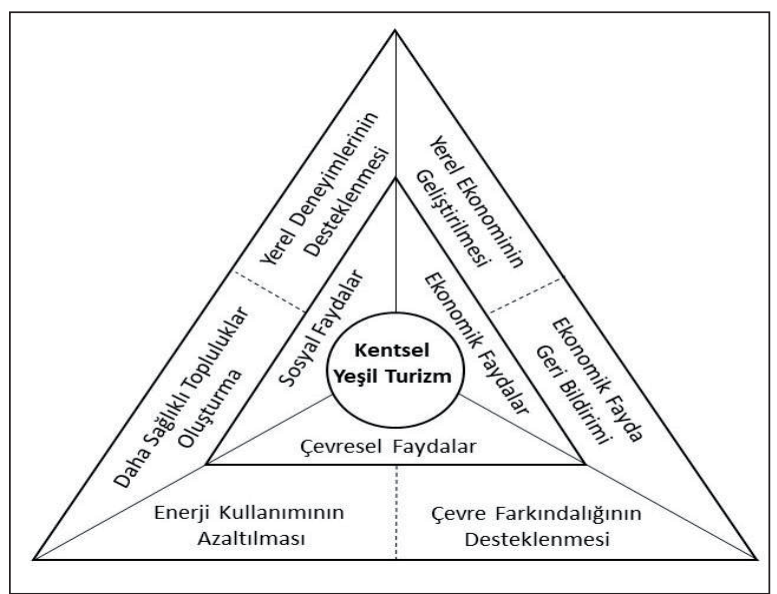

Şekil 2. Kentsel Yeşil Turizmin Avantajları

Kaynak: Dunlop 2013; Andari 2016. 
Ekonomik boyut: Yerel ürün ve hizmetlerin tüketilmesi, ekonomik faydaların yerelde kalması, ekonominin esneklik ve direnç kazanmasında rol oynamaktadır. Çevresel boyut: Ulaşımda bisiklet kullanarak ve yürüyerek enerji kullanımını azaltmayı, kentlerdeki nesneleri algılama ve eve daha yakın yerlere seyahati, kent-doğa ilişkisini canlandırmayı ve çevre bilincinin kazanılmasını teşvik etmektedir (Dunlop 2013; Andari 2016).

Kentsel yeşil turizmin tüm bu güçlü yönleri, kentlere rekabet avantajları verirken, diğer taraftan bazı güncel stratejiler de bu turizm türünün geleceğini garantilemektedir. Avrupa Birliği 2030 Biyoçeşitlilik Stratejisi'nde "kent ve çeperini yeşillendirme" en önemli eylemlerden biridir. $\mathrm{AB}$ Komisyonu doğayı şehirlere geri getirmek için, 2021 'in sonuna kadar nüfusu 20.000 ve daha fazla olan Avrupa kentlerini yeşillendirme planları yapmaya davet etmekte, bu planların kolay erişilebilir, ormanlar, parklar ve kentsel bahçeler, kentsel çiftlikler, yeşil çatılar ve duvarlar, ağaçlıklı sokaklar, kentsel çayırlar ve kentsel çitlerin yaratılmasına yönelik tedbirleri içermesi istenmektedir (European Commission 2020). Bütün bu hedefler ve yapılması planlananlar, kentsel ekoturizme yeni kapılar açacak, ona olan ilgiyi canlı tutacak ve yeni destinasyonlar kazandıracaktır.

\section{KENTSEL EKOTURIZM VE YEŞiL TURIZMDE BAŞARI ÖRNEKLERi}

\section{Kanada}

Toronto, Kanada'nın kentsel yeşil turizmde öncü ve en önemli kentlerinden biridir. Toronto'da turizmin trafik sıkışıklığı yarattığı, toplu taşıma sisteminin de bu yoğun trafiği engelleyemediği görülmüş, Yeşil Turizm Derneği'nin önerisiyle Toronto'yu çevresel sorumluluk bilinciyle keşfetmek isteyenler için “Toronto'nun Diğer Rehbe$r i$ " adı altında bir rehber hazırlanmıştır. Rehber için "Diğer Toronto'nun Anahtarı" tanımlaması yapilmaktadır (Green Tourism Association 2019). Rehberde turistlere doğaya saygı gösterme, kirliliği azaltma ve iyi bir çevre dostu olabilme konularında bazı ipuçları verilmekte, kent içi turların daha çok yürüyerek ya da toplu taşıma araçlarıy- la yapılması istenmektedir. Rehberde yalnızca çevreye saygılı işletmeler yer almaktadır (Butty vd. 2014).

Montréal, turistlere göre bir kentsel yeşil turizm destinasyonudur ve ilk göstergelerden biri, bisiklete binme alışkanlığıdır. Kentte yeşil sertifikalı restoranlar, çevre dostu oteller hizmet vermektedir. Kentte rehberli yürüyüş ve bisikletli turlar, turistlere sürdürülebilir koruma bilgileri verildikten sonra başlamaktadır. Montréal, Ulusal Coğrafya Toplumu'nun hazırladığı Jeoturizm Tüzüğünü imzalamış ve 2009 yılında kentsel jeoturizm rehber haritası yayınlanmıştır. Kentte ekoturlar, yürüyüşçüler ve bisikletliler için yeşil ve mavi yollar, yerli bitkiler, ağaçlar, kuş evleri ve yeşil örtülü duvarlarla süslü sokaklar, sürdürülebilir ve yeşil girişimler (sıfır karbon, sıfır atık, yeniden kullanım, geri dönüşüm vd.), eko-tasarım mobilya, giyim ve aksesuarlar, eko-mimari, eko-sorumlu iş ve kongre toplantıları, yeşil festivaller, ekomüzeler, botanik bahçeleri, büyük park komplekslerinin hepsi, kentsel yeşil turizmi desteklemektedir (Tourisme Montréal Tolkit 2012).

\section{Fransa}

Paris; çevresel, etik ve sosyal kaygıların gittikçe önem kazandığ bu çağda, Avrupa başkentleri arasında kentsel ekoturizmin çevresel, sosyo-kültürel ve ekonomik yansımalarını gördüğümüz en başarılı örneklerden biridir. Paris, hepsi belediye meclisi kararıyla geliştirilmiş ve korunmuş 400 yeşil alana ev sahipliği yapmaktadır. Paris'te bugün ekoturizm felsefesine uyumlu birçok yeniliklere gidilmekte ve turistlere çeşitli hizmetler sunulmaktadır. Kentteki birçok yeşil etiket ödüllü otel, çevreyi koruyan önlemler almaktadır (Frommers 2020). Başkent çevre dostu ulaşım araçlarıyla öncü sürdürülebilir turizm merkezi olarak gösterilmektedir Kentte turistlere yönelik Eko Yürüyüşler adı altında kentsel çevre yürüyüşleri organize edilmekte ve ilgili web siteleri bulunmaktadır. Ayrıca kentte sağlık-spor amaçlı yaya yürüyüşleri için beş kilometrelik Yeşil Gezinti Kuşağ $\imath$ (Coulée Verte/La Promenade Plantée) oluşturulmuştur. Bu yeşil kuşak, trafiği 1969'da durdurulmuş eski bir demiryolu hattının rotası- 
$\mathrm{n} 1$ takip etmekte, yer yer viyadüklerin üstünden, meydanlardan, piknik alanlarından ve tünellerden geçmektedir (Di Vita 2016). Bir diğer örnek, tarihi 19. yüzyıla inen Çiçekler Şehri (Cité des Fleurs) anlamina gelen bir caddedir ve Paris' in eşsiz yeşil vahalarından biridir. Bugün bu caddedeki yüzyıllık ağaçlar hem Parislilere hem de turistlere huzur ortamı sunmaktadır. Paris'e ekoturizm amacıyla geleceklere Yeşil Anahtar ya da $A B$ EkoEtiket logosu olan oteller önerilmektedir.

Angers kentinde eskiden bir çayır ve taşkın yatağ1 olan bölge iyileştirilerek, Maine Gölü Eğlence Parkı adıyla 1978'de halka açılmıştır (Fresison 2010). Korunmuş bir çevrede rahatlamak, gezinmek, piknik yapmak, güneşlenmek, gölde yüzmek, flora ve faunayı gözlemlemek, açıkhava ve su sporları yapmak, at binmek, yemek, toplantı organize etmek, hatta kampingde konaklamak isteyenler parka davet edilmektedir. Parkın yarısını yapay göl kaplamakta ve gölde yüzme, tekneler, yelkenliler ve kanolarla gezinti yapılabilmektedir. Parkın hem kentin kenarında hem de Maine nehri kıyısında yer alması, buraya ulaşlırken yine küçük parkların içinden geçilmesi, Angers'i kentsel ekoturizmin önemli bir destinasyonu haline getirmektedir (Parc de Loisir du Lac de Maine 2020).

Montpellier kenti için "kentsel ekoturizmin şampiyonu" denilmektedir. Belediye sınırları içindeki alanın yüzde 60 ' 1 kentleşmiş bölge, yüzde 40'1 parklar, korunan alanlar, ormanlar ve kırsal alanlardan meydana gelmektedir. Kentlere yeşil yatırım, şimdiki ve gelecek nesiller için kentsel yaşam kalitesine de yatırım sayılmaktadır. Bir Akdeniz kenti olarak Montpellier'de uzun vadeli "yeşil vizyon" sadakati, kentin geleceğini şekillendirmektedir. Montpellier'nin çevre tüzügünde, kentsel peyzajı iyileştirme ve koruma, eko ulaşım, doğal kaynakları daha iyi tanıma ve koruma, çevre eğitimi, çevre yönetimi için göstergelerin ve araçların geliştirilmesi kabul edilmiştir (Besse vd. 2014). Montpellier'deki bu yeşil tutku, kente gelen turisti de etkilemektedir. Botanik Bahçesi, Montmaur Ağaçlı̆̆ı, Lez nehri boyunca gezinti yolları, Belediye park ve bahçeleri, şato bahçeleri, Zooloji Parkı, ekolojik tarım parkı vd. turistlerin ziyaret ettikleri başlıca yeşil mekânları oluş̧tururken, kentten diş çevreye uzanan yürüyüş ve bisiklet yolları da kente ayrı bir çekicilik katmaktadır (Montpellier.fr. 2019).

\section{Yeni Zelanda}

Ekoturizm, Yeni Zelanda ile eşanlamlıdır, çünkü balina ve yunus gözlemleri de dâhil olmak üzere adaların eşsiz ve hayranlık uyandıran doğal harikalarını deneyimlemek, korunmuş plajları ve ormanları keşfetmek gibi çok sayıda fırsat vardır (Parker 2018). Ülkedeki Oamaru kasabasında kentsel ekoturizm, bir sürpriz gelişmeyle ortaya çıkmıştır. Bir mavi penguen kolonisinin buraya gelmesi ve yuva yapmasiyla, hem yerel halk hem de turistler onları izlemeye başlamıştır. Penguenleri gözlemeye ve korumaya dayalı bir kentsel ekoturizm projesi yapılmıştır. Böylece burası Oamaru'nun en önemli turistik noktası olmuştur. İki türlü ziyaret söz konusudur: Gündüz penguen yuvalarını gözlemleme turu; bir rehber eşliğindeki gece turu. İkinci tur Oamaru için daha önemlidir, çünkü gece turunu tercih eden turistlerin çoğu konaklama yaparak turizme daha fazla katkı sağlamaktadır (Jamaa 2010).

\section{SONUÇ}

Kentler, kırsal yerleşmelere göre çok işlevli ve çok nüfuslu olmalarının beraberinde, ayrıca küresel gelişmelere uyum sürecinde birçok sorunla karşı karşıyadır. Bunların çözümü için ekokent ve yavaş şehir gibi kentleri farklı boyutlara taşıyan yenilikçi girişimler görülmekte, aynı zamanda turizm, bazı kentlerin ekonomik kurtarıcısı, yeni gelişmelerin lokomotifi olmaktadır. O nedenle, kent turizminde klasikleşmiş destinasyonlara yenileri eklenmekte, diğer taraftan kendisi de değişim ve dönüşüme uğramaktadır. Nitekim kent turizmi ve ekoturizmin arakesitinde kentsel ekoturizm doğmuş, sürdürülebilirlik ilkeleri ve eko yaklaşımların bir ürünü olarak gerçek anlamda planlı ve projeli biçimde 2000'li yılların başından itibaren görülmeye başlamıştır.

Kentsel ekoturizmin, kent halkının yaşam kalitesi, ekolojik ve coğrafi değerlerin korunması, turistlerin beklentilerinin karşılanması ve tatilden doyum sağlamasında çok önemli katkıları vardır. Bu üstün ve ayrıcalıklı yapısına rağmen her 
kentte ekoturizmi uygulamak ve sürdürülebilir kılabilmek o kadar da kolay değildir. Bu açıdan dört tür kent daha avantajlıdır: Birincisi; tarihten gelen miras olarak o kentin zengin yeşil dokuya ve düzenlenmiş rekreasyonel alanlara sahip olması, ikincisi; kent planlamasında uzun yıllardan beri kentsel yeşil alanların geniş yer tutmasına çaba gösterilmesi ve çok sayıda park, bahçe ve korulukların yaratılması, üçüncüsü; ekokent, yavaş şehir, yavaş yemek, eko-mimari, eko-etiket, eko-ulaşım gibi günümüzün çevreci ve korumacı akımlarını benimseyen yerel yönetim ve kent halkının işbirliği içinde olması, dördüncüsü; büyük ölçüde turizme bağımlı kentlerin rekabet şanslarını artırmak üzere, turizmde güncel gelişmeleri takip etmeleri ve turist beklentilerini araştırmaları sonucu klasik kent turizmine birçok yenilikleri eklemeleridir. Bu kentlerin dişında kalanlarda ise kentsel ekoturizm çok sınırlı kalmakta ve amacına tam ulaşamamaktadır. Ancak; kentsel dönüşüm çalışmalarında teknolojik ve yaratıcı girişimlerle ekoturizm içerikli düzenlemeler yapılması, kısmen de olsa kent turizmine yeni bir kimlik kazandırabilmektedir.

Kentsel ekoturizm, yararları kadar, bazı gerilemelere ve olumsuz etkilere de yol açabilmektedir. Bunlar diğer turizm türlerinde görülenlerle benzerdir: yoğun ziyaretçiden ve aşırı kullanımdan dolayı mekânların yıpranması, kirlilik ve tükenme, denetimsizlik sonucu sosyal yıkımlar ve yozlaşmalar, başka yerlerden taklit ve kopyalama ile özgün yerel kimliğin yok olması, aş1rı müdahaleden görsel kirliliğin doğması gibi. Bütün bunlar doğadaki ekoturizm gibi kentteki ekoturizmin de çok iyi izlenmesi gerektiğini, geri dönüşlerle beslenerek sürekli iyileştirmelere gidilmesinin şart olduğunu göstermektedir. Burada kentsel ekoturizmi daha şanslı ve çözümleyici yapan tarafı, bu turizm türüne inanan ve kentin yaşanabilirliğini yüksek tutmak isteyen yerel yönetimlerin varlığı, eko algısı açık kent halkı ve onların sivil toplum örgütlerinin bulunmasıdır.

\section{DEĞERLENDIRME}

Kentsel ekoturizmin kuramsal çerçevesi ve uygulamalarının son yirmi yıldan bu yana belli bir zemine oturmasına rağmen, alanyazında gö- rüldüğü üzere farklı disiplinlerden araştırmalar henüz çok yeni, sayı olarak da oldukça azdır. Bu niteliksel ve niceliksel zayıflığın nedenleri; kentsel ekoturizm kavramı ve içeriğinin henüz tam bilinmemesi ve gelişme sürecini yaşaması, uluslararası turizmde pek tanınmaması, olumlu ya da olumsuz etkilerinin ortaya çıkması için uzun bir sürenin geçmemiş olmasına bağlanabilir. Buna karşılık; şehir, bölge, rekreasyon, destinasyon planlaması ve yönetimi, peyzaj mimarlığı, turizm ekonomisi ve işletmeciliği, turizm coğrafyası gibi alanlarda kentsel ekoturizmle ilgili araştırılabilecek pek çok konu bulunmaktadır. Turizm coğrafyası yaklaşımıyla şu konular önerilebilir:

- Ekoturizmin kentlere taşınmasıyla birlikte ilkelerine bağlllık ve aktivitelerinde nasıl bir değişim olmaktadır? Bu değişim kentsel mekâna nasıl yansımaktadır? Bu yapısal değişim turistler tarafından nasıl algılanmaktadır?

- Kent turizmine eko yaklaşımlarla yenilikler getirilmesi hakkında kent halkının görüşleri nelerdir?

- Kentsel ekoturizmin çekicilikleri nelerdir? Bu çekicilikler kentin alg1, imaj ve marka değerleri üzerinde ne kadar etkilidir?

- Kentsel dönüşüm ve terkedilmiş sanayi bölgelerinin iyileştirilmesi yoluyla kazanılan çok işlevli yeni rekreasyon alanlarının kentsel ekoturizmle ilişkisi ve etkileri nelerdir?

- Kentsel ekoturizm hizmetleri ve aktiviteleri, kentsel arazi kullanımını nasıl etkilemektedir?

- Kentsel ekoturizm ziyaretçilerinin demografik özellikleri, geldikleri yerler, beklentileri, tercihleri, etkilendikleri çekicilikler ve hizmetler hangileridir?

- Karşılaştırmalı araştırmalar: Çekicilikler, destinasyonlar, hizmetler, ürünler, aktiviteler, talep, etki-etkileşim vd.

Bütün bu turizm coğrafyası temelli konular, disiplinlerarası olarak araştırıldığı takdirde, kentsel ekoturizme bilimsel açıdan daha derinlikli katkı sağlayacak ve tanınırlığını da arttırmış olacaktır. 


\section{KAYNAKÇA}

Accor (2015). L'écotourisme Urbain: Le Vert S'installe en Ville, https://group.accor.com/fr-FR/Actualites/2017/02/15/ urban-ecotourism-greening-cities/, (Erişim tarihi: 30.04.2020).

Andari, R. (2016). Green Tourism Role in Creating Sustainable Urban Tourism, South East Asia Journal of Contemporary Business, Economics and Law, 11 (2): 18-26.

Ataberk, E., Kaplanoğlu, E. ve Meriç, M. K. (2012). Bergama'nın Ekoturizm Sektör Analizi. İzmir: İzmir Kalkınma Ajansı Araştırma Projesi.

Besse, F., Conigliaro, M., Fages, B., Gauthier, M., Mille, G., Salbitano, F. ve Sanesi, G. (2014). Montpellier, Green City, Unasylva: An International Journal of Forestry and Forest Industries, "A New Dynamic for Mediterranean Forests", 65 (1): 23-28.

Bibri, S. E. ve Krogstie, J. (2020). Smart Eco-City Strategies and Solutions for Sustainability: The Cases of Royal Seaport, Stockholm, and Western Harbor, Malmö, Sweden, Urban Science, 4 (11): 1-42.

Butty, A., Berclaz, J., Pfefferlé, M. ve Maret, J. (2014). Urban Ecotourism, Case Study, Module 713. Haute Ecole de Gestion Tourisme. İsviçre: Valais.

Chang, C.C. ve Sheppard, E. (2013). China's Eco-cities as Variegated Urban Sustainability: Dongtan Eco-City and Chongming Eco-Island, Journal of Urban Technology, 20 (1): 57-75.

Çetinkaya, Ç. (2013). Eko-Kentler: Kent ve Doğa İlişkisinde Yeni Bir Sistem Tasarımı, Türk Bilimsel Derlemeler Dergisi, 6 (1): 12-16.

Deschamps, L. (2010). Présentation des Grandes Tendances du Tourisme et Des Enjeux Pour les Villes Moyennes, Le Tourisme, Une Opportunité Pour Dynamiser Les Villes Moyennes, Actes du Colloque, 4. Fransa: Paris.

Di Vita, D. (2016). Sustainable Ecotourism in Paris: La Vie en Vert. https://www.likealocalguide.com/paris/promenadeplantee-coulee-vertel, (Erişim tarihi: 30.04.2020).

Dodds, R. ve Joppe, M. (2001). Promoting Urban Green Tourism: The Development of the Other Map of Toronto, Journal of Vacation Marketing, 7 (3): 261-267.

Emekli, G. (2011). Öğrenen Turizm Bölgeleri, Kentler ve Kent Turizmine Kuramsal Yaklaşım, Ege Coğrafya Dergisi, 20 (2): 27-39.

European Commission (2020). EU Biodiversity Strategy for 2030. Brüksel: COM (2020) 380 Final, Belçika.

Fresison, L. (2010). Urban Ecotourism-The Case of Lac de Maine Leisure Park, Ecoclub.com, https://ecoclub.com/ education/articles/305-urban-ecotourism-the-case-of-lac-demaine-leisure-parkl, (Erişim tarihi: 16.04.2020).

Frommer's, Things to Do in Paris, https://www.frommers.com/ destinations/paris/, (Erişim tarihi: 23.04.2020).

Green Tourism Association (2019). Green Tourism. http://greentourism.cal, (Erişim tarihi: 18.03.2020).

Herdman, E. A. (Çev. Z. Dörtbudak). (2006). Derleme Makale Yazımında, Konferans ve Bildiri Sunumu Hazırlamada Pratik Bilgiler, Hemşirelikte Eğitim ve Araştırma Dergisi, 3 (1): 2-4.
Higham, J. ve Lück, M. (2002). Urban Ecotourism: A Contradiction in Terms?, Journal of Ecotourism, 1 (1): 36-51.

İşçi, B., Pınarc1, N. ve Gül, A. (2018). Kentsel Ekoturizm ve Isparta Kent Merkezinde Uygulanabilirliği, Karabük Üniversitesi Sosyal Bilimler Enstitüsü Dergisi, 8 (1): 101-115.

Jamaa, S. (2010). Écotourisme Urbain: Des Villes Réapproprient Leur Héritage Naturel, Reseau Vieille Tourism, https://veilletourisme.ca/2010/09/29/, (Erişim tarihi: 18.03 .2020$)$.

Joppe, M. ve Dodds, R. (1998). Urban Green Tourism: Applying Ecotourism Principles to the City, Travel and Tourism Research Association-Canada, Toronto. http:// www.csu.edu/cerc/researchreports/documents/UrbanGreenTourism1998.pdf, (Erişim tarihi: 18.03.2020).

Kavcar, B. (2017). Eko-Kent Modeli, http://sbpturkiye.com/ekokent-modeli.html/, (Erişim tarihi: 18.03.2020).

Meydan Yıldız, S. G. (2016). Çevre Bilinci ve Eko-Kent Planlaması: Gölbaşı Özel Çevre Koruma Bölgesi Örneği (Basılmamış Doktora Tezi). Ankara: Ankara Üniversitesi Sosyal Bilimler Enstitüsü.

Montpellier.fr. (2019). Les Parcs et Les Jardins, Espaces Verts, Les Coins de Nature, https://www.montpellier.fr/1125les-espaces-verts-montpellier-ville-verte-.htmll, (Erişim tarihi: 16.04.2020).

Parc de Loisir du Lac de Maine, Parc de Loisirs du Lac de Maine: Un Environnement Protégé, http://www.lacdemaine. frl, (Erişim tarihi: 05.05.2020).

Parker, J. (2018). Eco-Friendly Destinations you Must Visit Around the World, "New Zealand", https://theculturetrip.com/europelarticles/11-eco-friendly-destinations-youmust-visit-around-the-worldl, (Erişim tarihi: 23.04.2020).

Planeta.com (2006). Urban Ecotourism Declaration, https:// planeta.com/urban-ecotourism-declaration, (Erişim tarihi: 18.03.2020).

Spirou, C. (2011). Urban Tourism and Urban Change. Cities in a Global Economy. Taylor \& Francis e-Library.

Şarkaya İçellioğlu, C. (2014). Kent Turizmi ve Marka Kentler: Turizm Potansiyeli Açısından İstanbul'un SWOT Analizi, İstanbul Üniversitesi Sosyal Bilimler Dergisi, 1: 37-55.

Tekin, C. (2017). Yavaş Turizm ve Yavaş Turist: Cittaslow Seferihisar'da Karşılaştırmalı Bir araştırma (Basılmamış Yüksek Lisans Tezi). Batman: Batman Üniversitesi Sosyal Bilimler Enstitüsü.

Tourisme Montréal Tolkit (2012). Tourisme Vert à Montréal: Service de la Recherche. Gouvernement du Canada.

Urban Strategy Partners (2017). Turizm ve Kentler Raporu. Londra: İngiltere.

Ville de Lausanne (2006). Lausanne Objectif Qualité de Vie: Le Développement Durable en Actions. İsviçre: Lozan.

Weaver, D. B. (2015). Mass and Urban Ecotourism: New Manifestions of an Old Concept, Tourism Recreation Research, 30 (1): 19-26.

Wu, Y., Wang, H. L. ve Ho, Y. F. (2009). Urban Ecotourism: Defining and Assessing Dimensions Using Fuzzy Number Construction, Tourism Management, 31: 739-743.

Zorzi, A. (2015). L'écotourisme Permet-il de Modifier les Comportements des Citadins en Milieu Métropolitain? Le Cas de Paris (Master Tourisme et Hôtellerie). Toulouse: Université de Toulouse II-Jean Jaures. 


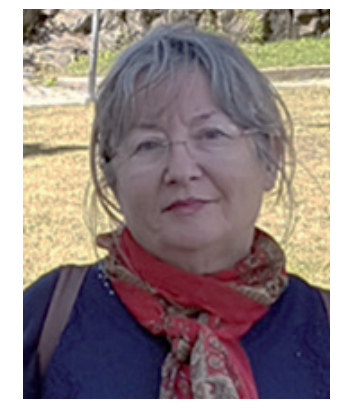

Füsun BAYKAL

İstanbul Üniversitesi Edebiyat Fakültesi Coğrafya Bölümü’nden mezun oldu (1979). Yüksek lisans derecesini Ege Üniversitesi Sosyal Bilimler Enstitüsü Coğrafya Anabilim Dalı'ndan (1984), doktora derecesini de yine aynı üniversite ve aynı anabilim dalından aldı (1988). Ege Üniversitesi'nde çalışmaya başladı (1981). Tunus Hükümeti'nin Araştırma Burslusu olarak başkent Tunus'ta bulundu (1990-1991 Öğretim Yılı). Doçentlik unvanını Beşeri ve İktisadi Coğrafya alanında aldı (1994). Profesörlüğe Ege Üniversitesi'nde yükseltildi (2004). Halen Ege Üniversitesi Edebiyat Fakültesi Coğrafya Bölümü’nde görev yapmaktadır. Temel çalışma alanları, turizm coğrafyası, kırsal kalkınma ve kırsal turizm, turistik rotalar ve kültürel coğrafyadır.

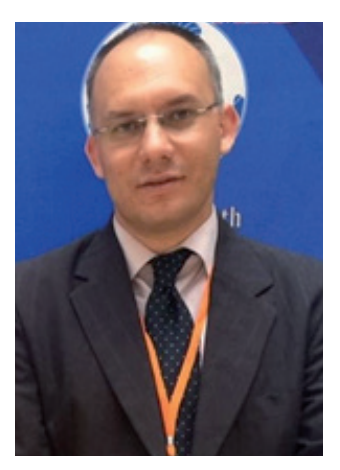

Emre ATABERK

Lisans eğitimini Gazi Üniversitesi Ticaret ve Turizm Eğitim Fakültesi Turizm Eğitimi Bölümü’nde (2001). Yüksek lisansını Dokuz Eylül Üniversitesi Sosyal Bilimler Enstitüsü Turizm İşletmeciliği Anabilim Dalı'nda (2007), doktorasını Ege Üniversitesi Sosyal Bilimler Enstitüsü Coğrafya Anabilim Dalı'nda tamamladı (2020). Kültür ve Turizm Bakanlığı'na bağıı Profesyonel Turist Rehberi oldu (2007). Ege Üniversitesi Bergama Meslek Yüksekokulu Turizm ve Otel İşletmeciliği Programı'nda Öğretim Görevlisi olarak çalışmaya başladı (2007). Halen, Ege Üniversitesi Bergama Meslek Yüksekokulu'nda görev yapmaktadır. Temel çalışma alanları, turizm coğrafyası, kültür turizmi, kültürel miras, ekoturizm, kırsal turizm, sürdürülebilir turizm ve turist rehberliğidir.

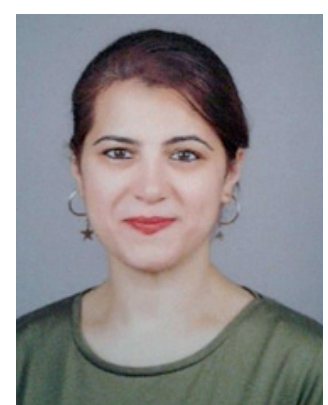

\section{Hayriye ALPARSLAN}

Ege Üniversitesi Edebiyat Fakültesi Coğrafya Bölümü'nden mezun oldu (2019). Ege Üniversitesi Sosyal Bilimler Enstitüsü Coğrafya Anabilim Dalı'nda tezli yüksek lisans yapmaktadır. Tez yazım aşamasındadır. Temel ilgi alanları, turizm coğrafyası, kent coğrafyası, davranışsal coğrafya, CBS ve kültürel coğrafyadır. 